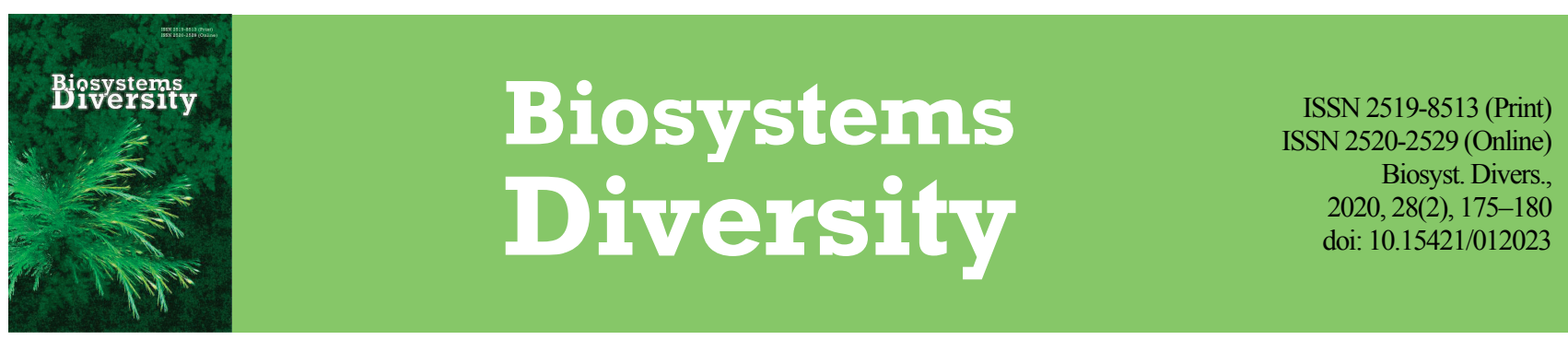

\title{
Effect of crystalline and amorphic phenol on characteristics of peptidases and glycosidases in chironomid larvae
}

\author{
V. V. Kuz'mina*****, E. Y. Chornaya**, E. A. Kulivatskaya*, G. V. Zolotareva**, V. A. Sheptitskiy**,**** \\ *I. D. Papanin Institute of Biology of Inland Waters RAS, Borok, Russia \\ **T. G. Shevchenko State University, Tiraspol, Moldova \\ ***Yaroslavl State Agricultural Academy, Yaroslavl, Russia \\ ****Institute of Physiology and Sanocreatology, Chisinau, Moldova
}

Article info

Received 09.04.2020

Received in revised form 03.05 .2020

Accepted 04.05.2020

I. D. Papanin Institute of Biolog of Inland Waters RAS, Borok,

152742, Russia.

Tel:+748-547-24-207.

E-mail:vkuzmina@ibiw.ru

T. G. Shevchenko State

University, 25 October st., 128 ,

Tiraspol, 3300, Moldova.

Tel: $+373-533-79-551$.

E-mail:

zolotariova_g_v@mail.ru

Yaroslavl State Agricultural Academy, Tutaevskoe Shosse, 58

Yaroslavl, 150042, Russia.

Tel.:+7-982-650-70-36.

E-mail:vkuzmina@ibiw.ru

Institute of Physiology

and Sanocreatology,

Academiei st., 1 ,

Chisinau, 2028, Moldova

Tel.:+373-697-53-782

E-mail: septitchi@mail.ru

\section{Introduction}

As is known, phenol formed during the metabolism of aquatic organisms, as well as during biochemical decomposition and transformation of organic substances that occur in water and in bottom sediments, does not pose a threat to ecosystems (Zaprometov, 1974; Michałowicz \& Duda, 2007; Ali et al., 2011). However, phenol and its derivatives become dangerous for aquatic organisms when industrial waste, especially oil and shale processing enterprises, coke, pulp and paper, woodworking, metallurgical, as well as aniline and paint industries, enters the water (Orlov et al., 2002; Maistrenko \& Klyuev, 2004; Singh \& Chandra, 2019). Phenol, being a poison of neuroparalytic action, causes severe dysfunction of the central nervous system (Lukyanenko, 1983; Flerov, 1989), largely due to blocking of ion channels (Michałowicz \& Duda, 2007). In addition, phenol causes skin necrosis (Clayton \& Clayton, 1994; Mai, 2012), damages the kidneys (Flerova \& Zabotkina, 2012; Mai, 2012), muscles (Ford et al., 2001), eyes (Michałowicz \& Duda, 2007), metabolism (Hori et al., 2006, 2008) endocrine (Gad \& Saad, 2008) and the immune system (Taysse et al., 1995; Mikryakov et al., 2001). The effect of phenol on the activity of digestive enzymes in fish is also known (Kuz'mina et al., 2017a). doi:10.15421/012023
Kuz'mina, V. V., Chornaya, E. Y., Kulivatskaya, E. A., Zolotareva, G. V., \& Sheptitskiy, V. A. (2020). Effect of crystalline and amorphic phenol on characteristics of peptidases and glycosidases in chironomid larvae. Biosystems Diversity, 28(2), 175-180. The effects of crystalline and amorphous phenol $(0.5 \mathrm{mmo} / \mathrm{L})$ on the characteristics of glycosidases, as well as casein-lytic a greater extent in the case of the lower fraction). Amorphous phenol increased the activity of casein-lytic peptidases in compariThe degree of the increase of enzyme activity in the temperature optimum zone of casein-lytic and hemoglobin-lytic peptidases The temperature optimum of the studied peptidases of chironomid larvae, regardless of the experimental conditions, corresponds phenol decreased the $\mathrm{Q}_{10}$ values at a temperature of $40-50^{\circ} \mathrm{C}$. The $\mathrm{Q}_{10}$ values of casein-lytic peptidases increased in most cases, pepidases of all tissues of chirononid larvae in the presence of amorphous phenol th both temperature zones decreased. Thr values of the process of starch hydrolysis in the presence of crystalline phenol decreased. The amorphous phenol changed the $\mathrm{E}_{\mathrm{ac}}$

Keywords: amorphous phenol; chironomid larvae; glycosidases; peptidases; enzyme characteristics.

It is important to note that crystalline phenol was used earlier in toxicological studies (Lukyanenko, 1983; Flerov, 1989). In the recent years it has been replaced by amorphous phenol having the same formula $\left(\mathrm{C}_{6} \mathrm{H}_{5} \mathrm{OH}\right)$. However, amorphous phenol differs significantly from crystalline phenol both externally (a solid mass or loose "clumps" of yellowish colour) and in its ability to melt after 6-12 months, not only at room temperature, but also at a temperature of $6-8^{\circ} \mathrm{C}$. As is known, the melting point of crystalline phenol is $40.9{ }^{\circ} \mathrm{C}$ (Goronovsky et al., 1987). It is important to note that two distinct fractions are formed upon the melting of amorphous phenol: a small upper fraction and a lower fraction, the volume of which is 4-5 times larger. Herewith the properties of phenol changed. So, the crystalline phenol and its derivatives (4-chlorophenol, 4-nitrophenol or 2,4-dinitrophenol) inhibits the activity of peptidases that function in the intestinal mucosa in fish of the fam. Cyprinidae and Esocidae, and in some cases Percidae (Kuz'mina et al., 2017a). The effects of amorphous phenol in the same fish species are usually significantly different from those of crystalline phenol. Moreover the inhibition is sometimes replaced by stimulation (Kuz'mina et al., in press).

Information on the characteristics of enzymes functioning in the whole body of fish feed objects is fragmentary. Chironomids are convenient to eliminate the existing gaps. Chironomid larvae play an im- 
portant role in aquatic food chains (Zilli et al., 2008). Their abundant populations are significant in aquatic food chains because larval chironomids can be a food source for larger invertebrates (Pinder, 1986) and fish (Gerking, 1994; Kamler et al., 2008; Gerasimov, 2015). They are favourite feed objects of various benthophages (Ivanova et al., 1978). Chironomids are a diverse group occupying a number of ecological niches and using a wide range of feed sources. They are characterized by four stages of development: the egg, larva, pupa and adults. The development of larvae also goes through four stages. Chironomid larvae feed as grazers on algae during the first stage of development and on detritus and even on other animals as detrivores during the subsequent stages of larval development (Pinder, 1986; Wardiatno \& Krisanti, 2013). It was previously shown that in vitro crystalline phenol and its derivatives (2chlorophenol, 4-chlorophenol, 2-nitrophenol and 2-aminophenol) in high concentrations $(62.5-500 \mathrm{mg} / \mathrm{L})$ significantly increase the activity of casein-lytic peptidases in the whole body of chironomid larvae Chironomus sp. However, 2,4-dinitrophenol decreases consistently the activity of peptidases (Kuz'mina et al., 2016). These data differed significantly from the results obtained in one study of fish (Kuz'mina et al., 2017a). However, the information on the temperature characteristics of peptideses (Kuz'mina, 1999; Kuz'mina et al., 2018) and glycosidases (Kuz'mina, 1999) in the whole body of chironomid larvae was fragmentary (Kuz'mina et al., 2017b). Information on the effect of phenol on the characteristics of enzymes destroying carbohydrate components of own tissues of potential fish feed objects is lacking in the available literature. The aim of the work was to study the effect of crystalline and amorphous phenol on the activity and some characteristics of peptidases and glycosidases, which function in the whole body of chironomid larvae in vitro.

\section{Material and methods}

The object of study is chironomid Chironomus plumosus larvae. The average weight of one larva in different experiments was 6.0 or $7.5 \mathrm{mg}$. Small chironomid larvae were selected from the bottom sediments of the Kuchurgan Reservoir, and larger ones were obtained from a pet-shop. Homogenates of previously crushed and carefully mixed dozens of larvae were used as enzymatically active preparations. All operations were carried out in the cold. Aliquots of samples $(0.5-1.0 \mathrm{~g})$ were homogenized in a glass homogenizer with a small amount of Ringer's solution for cold-blooded animals $(103 \mathrm{mM} \mathrm{NaCl}, 1.9 \mathrm{mM} \mathrm{KCl}$, $0.45 \mathrm{mM} \mathrm{CaCl}_{2}, \mathrm{pH} 7.4$ ) at a temperature of $2-4{ }^{\circ} \mathrm{C}$. For this, a glass homogenizer was placed in a glass with ice. Then the homogenate was diluted with Ringer's solution until the final dilution of 1:99. The homogenate and substrate were adjusted to $\mathrm{pH} 7.4$ using a $\mathrm{pH}$ meter $\mathrm{pX}-150 \mathrm{MI}$. The activity of enzymes was determined at a temperature of $20^{\circ} \mathrm{C}$, the temperature dependence of enzymes in the range $0-70{ }^{\circ} \mathrm{C}(0,10,20$, $30,40,50,60$ or $70{ }^{\circ} \mathrm{C}$ ) and continuous stirring. The $\mathrm{pH}$ of homogenate and substrate was 7.4. To assess the effect of crystalline or amorphous phenol on enzyme activity, initially $0.25 \mathrm{~mL}$ of homogenate and $0.25 \mathrm{~mL}$ of phenol solution were incubated at a concentration of $1 \mathrm{mmol} / \mathrm{L}$. Since the phenol concentration in the preincubate decreased by two times, its real concentration was $0.5 \mathrm{mmol} / \mathrm{L}$. Through $1 \mathrm{~h}$ after the start of preincubation, $0.5 \mathrm{~mL}$ of the substrate was added to the tubes and the mixture was incubated for another $30 \mathrm{~min}$. All operations were carried out with continuous stirring. In the control, instead of $0.25 \mathrm{~mL}$ of phenol solution, $0.25 \mathrm{~mL}$ of Ringer's solution was added to the homogenate.

The activity of glycosidases (the total activity of $\alpha$-amylase, $\gamma$-amylase, and enzymes of the maltase group) in the whole body of chironomid larvae was evaluated by increasing the concentration of hexoses using the Nelson method in the modification of Ugolev \& Jesuitova (1969). A soluble starch solution (1\%) was used as a substrate. The activity of peptidases (mainly the activity of trypsin, chymotrypsin and, to a lesser extent, the activity of elastase, carboxypeptidases, aminopeptidases and dipeptidases) was evaluated by increasing the concentration of tyrosine using the Folin-Ciocalteu reagent (Kuz'mina, 1999). The colour intensity was evaluated using a photocolorimeter (KFK-2) at $\lambda=670 \mathrm{~nm}$. The level of enzyme activity was judged by the increment of reaction products per 1 minute of incubation of the substrate and the enzymatically active preparation, taking into account the background (the amount of hexoses or tyrosine in the original homogenate), calculating per $1 \mathrm{~g}$ of wet tissue weight, $\mu \mathrm{mol} /(\mathrm{g} \cdot \mathrm{min})$. The temperature coefficients $\left(\mathrm{Q}_{10}\right)$ were calculated by the traditional way. The values of the activation energy $\left(\mathrm{E}_{\mathrm{act}}\right)$ were determined by the Arrhenius' graphical method using the formula: $\mathrm{E}_{\text {act }}=2.3 \times 1.987 \times \mathrm{T}_{2} \mathrm{~T}_{1}\left(\log \mathrm{V}_{2}-\log \mathrm{V}_{1}\right) /$ $\left(\mathrm{T}_{2}-\mathrm{T}_{1}\right)$, where 2.3 is the transition modulus of the decimal logarithm in natural, 1.987 - gas constant, $\mathrm{T}$ - temperature, ${ }^{\circ} \mathrm{K}\left({ }^{\circ} \mathrm{K}={ }^{\circ} \mathrm{C}+273\right)$, $\mathrm{V}-$ reaction rate.

Data was processed statistically using Statistica 10 program (StatSoft Inc., USA, 2011). The significance of the difference between controls and treatments were evaluated using ANOVA. Differences were considered significant at $\mathrm{P}<0.05$.

\section{Results}

The effect of amorphous phenol on the activity and temperature dependence of casein-lytic and hemoglobin-lytic peptidases in the whole body of chironomid larvae, $\mathrm{pH} 7.4$. At $20^{\circ} \mathrm{C}$ the activity of casein-lytic peptidases was $0.63 \pm 0.10$ and $0.94 \pm 0.20 \mu \mathrm{mol} /(\mathrm{g} \cdot \mathrm{min})$ in control and in the experiment. At the same temperature the differences in the activity of hemoglobin-lytic peptidases were not statistically significant between the control and the experiment: $1.03 \pm 0.36$ and $1.37 \pm 0.08$ $\mu \mathrm{mol} /(\mathrm{g} \cdot \mathrm{min})$, respectively. The study of peptidase activity over a wide temperature range showed that the optimum temperature of peptidases, regardless of the substrate and the presence of amorphous phenol, corresponds to $40^{\circ} \mathrm{C}$ (Fig. 1).
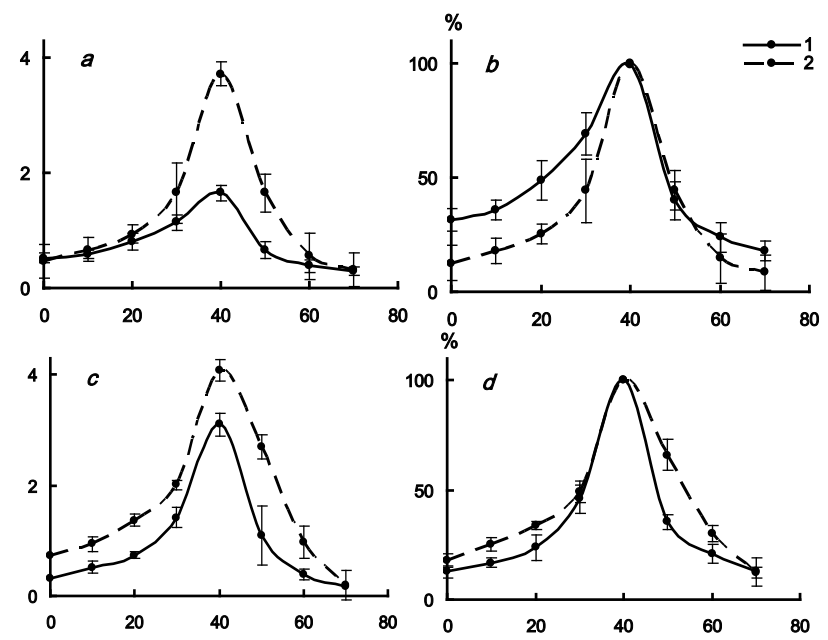

Fig. 1. The effect of amorphous phenol on the temperature dependence of casein-lytic $(a, b)$ and hemoglobin-lytic $(c, d)$ peptidases in the whole body of chironomid larvae $(\mathrm{pH} 7.4, \mathrm{x} \pm \mathrm{SE}, \mathrm{n}=5)$ : on the abscissa axis - temperature $\left({ }^{\circ} \mathrm{C}\right)$, on the ordinate axis - on $a$ and $c$-peptidase activity $(\mu \mathrm{mol} /(\mathrm{g} \cdot \mathrm{min}))$, on $b$ and $d$-relative

enzyme activity ( $\%$ of the maximum activity taken as 100 );

1 - in the absence of amorphous phenol, 2 - in the presence of the amorphous phenol

At the same time, differences in the curve shape of the temperature dependence of casein-lytic and hemoglobin-lytic peptidases, which function in the absence or presence of amorphous phenol, were revealed. So, in the range of $0-20^{\circ} \mathrm{C}$, the activity values of casein-lytic peptidases in the control and the experiment were extremely close. In the latter case, the activity of casein-lytic peptidases significantly increased in the temperature zone of $30-50{ }^{\circ} \mathrm{C}$. So, the activity of casein-lytic peptidases in the experiment exceeded that in the control at a temperature of $40{ }^{\circ} \mathrm{C}$ by 2.3 times. As a result, the relative activity of caseinlytic peptidases in the zone of $0-30{ }^{\circ} \mathrm{C}$ in the presence of amorphous phenol was much lower than in the control. Unlike casein-lytic peptideses, the absolute values of hemoglobin-lytic peptidase activity increased under the influence of amorphous phenol over a wider temperature range $\left(0-60^{\circ} \mathrm{C}\right)$. However, the degree of increase of enzymatic activity 
in the temperature optimum zone was lower than that of casein-lytic peptidases: the level of enzymatic activity in the experiment was 1.8 times higher than in the control.

The effect of crystalline phenol on the activity and characteristics of glycosidases in the whole body of chironomid larvae, $p H$ 7.4. Since the above data differed significantly from the previously obtained results (stimulation instead of inhibition), we investigated the effect of crystalline phenol on the activity and temperature dependence of glycosidases in the whole body of chironomid larvae. The activity of glycosidases in the whole body of smaller chironomid larvae from the Kuchurgan Reservoir at a standard temperature $\left(20^{\circ} \mathrm{C}\right)$ corresponded to $4.81 \pm 0.44 \mu \mathrm{mol} /(\mathrm{g} \cdot \mathrm{min})$, in the presence of crystalline phenol $-3.74 \pm 0.38 \mu \mathrm{mol} /(\mathrm{g} \cdot \mathrm{min})$. When studying the temperature dependence, the maximum glycosidase activity in the whole body of chironomid larvae was observed at a temperature of $50{ }^{\circ} \mathrm{C}: 7.47 \pm 0.24 \mu \mathrm{mol} /(\mathrm{g} \cdot \mathrm{min})$ in control and $6.64 \pm 0.28 \mu \mathrm{mol} /(\mathrm{g} \cdot \mathrm{min})$ in the presence of phenol (Fig. 2). In the temperature zone $0-20^{\circ} \mathrm{C}$, the differences between the control and the experiment were statistically significant $(\mathrm{P}<0.05)$. At a temperature of $0{ }^{\circ} \mathrm{C}$, the level of relative enzymatic activity in the control and experiment was $38.2 \%$ and $34.4 \%$ of the maximal activity, respectively.
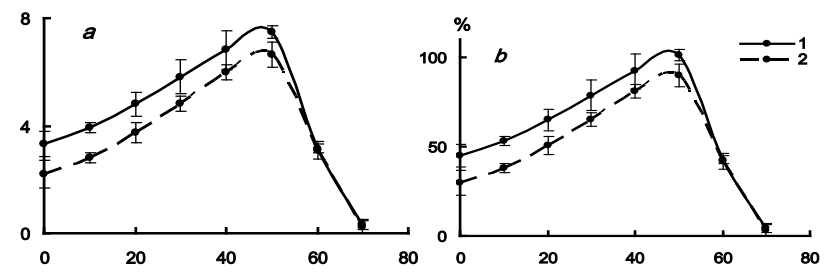

Fig. 2. The effect of crystalline phenol on the temperature dependence of glycosidases in the whole body of chironomid larvae $(\mathrm{pH} 7.4, \mathrm{x} \pm \mathrm{SE}, \mathrm{n}=5)$ : on the abscissa axis - temperature

$\left({ }^{\circ} \mathrm{C}\right)$; on the ordinate axis: on $a$ - the enzyme activity $(\mu \mathrm{mol} /(\mathrm{g} \cdot \mathrm{min}))$, on $b$ - the relative enzyme activity

( $\%$ of the maximum activity taken as 100$) ; 1-$ in the absence of phenol, 2 - in the presence of phenol

The effect of various fractions of amorphous phenol on the activity and characteristics of glycosidases in the whole body of chironomid larvae, $\mathrm{pH}$ 7.4. The activity of glycosidases in the whole body of larger chironomid larvae at standard temperature $\left(20^{\circ} \mathrm{C}\right)$ corresponded to $0.63 \pm 0.09 \mu \mathrm{mol} /(\mathrm{g} \cdot \mathrm{min})$. The activity values of glycosidases in the whole body of chironomid larvae in the presence of the upper and the lower fractions of amorphous phenol were $0.48 \pm 0.04$ and $0.45 \pm$ $0.05 \mu \mathrm{mol} /(\mathrm{g} \cdot \mathrm{min})$, respectively. When studying the temperature dependence, the maximum glycosidase activity in all experimental variants was noted at a temperature of $50{ }^{\circ} \mathrm{C}: 2.09 \pm 0.11,1.33 \pm 0.07$, and $1.05 \pm 0.07 \mu \mathrm{mol} /(\mathrm{g} \cdot \mathrm{min})$, respectively (Fig. 3). At 20 and $30{ }^{\circ} \mathrm{C}$, the differences between the level of glycosidase activity in the control and two experimental groups of chironomid larvae were statistically significant $(\mathrm{P}<0.05)$. At a temperature of $0{ }^{\circ} \mathrm{C}$, the level of relative enzyme activity in the control and two experimental groups of chironomid larvae was $14.8 \%, 17.3 \%$, and $24.8 \%$ of the maximum activity, respectively.

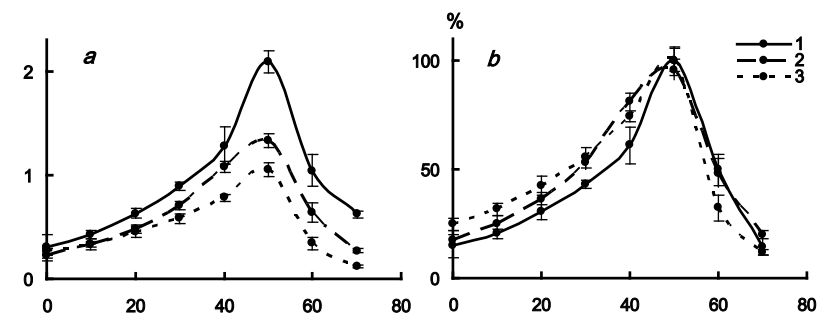

Fig. 3. The effect of different fractions of amorphous phenol on the temperature dependence of glycosidases in the whole body of chironomid larvae $(\mathrm{pH} 7.4, \mathrm{x} \pm \mathrm{SE}, \mathrm{n}=5)$ : on the abscissa axis temperature $\left({ }^{\circ} \mathrm{C}\right)$; on the ordinate axis: on $a$ - the enzyme activity $(\mu \mathrm{mol} /(\mathrm{g} \cdot \mathrm{min}))$, on $b-$ the relative enzyme activity $(\%$ of the maximum activity taken as 100); 1 - in the absence of amorphous phenol, 2 - in the presence of the upper fraction of amorphous phenol,

3 - in the presence of the lower fraction of amorphous phenol
A study of the effect of amorphous phenol on the $\mathrm{pH}$ dependence of glycosidases in the whole body of larger chironomid larvae showed that in the presence of the upper and lower fractions of amorphous phenol, the level of enzyme activity decreases over the entire range of $\mathrm{pH}$ values studied (Fig. 4). So, the activity of glycosidases in the whole body of chironomid larvae at $\mathrm{pH} 7.0$ and a temperature of $20^{\circ} \mathrm{C}$ corresponded to $4.77 \pm 0.43 \mu \mathrm{mol} /(\mathrm{g} \cdot \mathrm{min})$. In the presence of the upper and lower fractions of amorphous phenol activity of glycosidases were 3.77 \pm 0.38 and $3.18 \pm 0.43 \mu \mathrm{mol} /(\mathrm{g} \cdot \mathrm{min})$, respectively. The presence of phenol does not affect the optimum $\mathrm{pH}$ of glycosidases (8.0). Moreover, the values of the relative activity of glycosidases in almost the entire $\mathrm{pH}$ range in the control and two experimental groups of chironomid larvae are similar, especially in the case of the upper fraction.

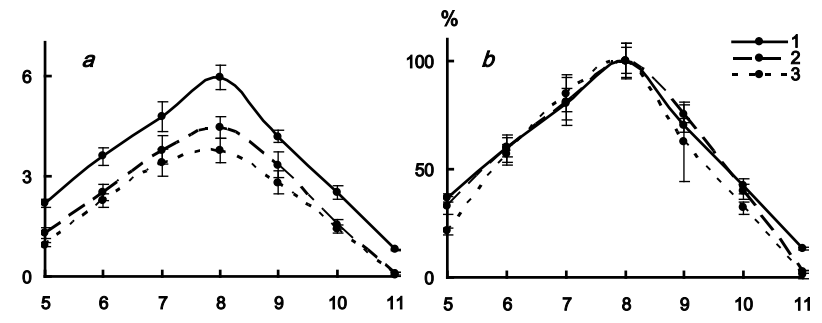

Fig. 4. The effect of different fractions of amorphous phenol on the $\mathrm{pH}$ dependence of glycosidases in the whole body of chironomid larvae (temperature $20^{\circ} \mathrm{C}, \mathrm{x} \pm \mathrm{SE}, \mathrm{n}=5$ ): on the abscissa axis $-\mathrm{pH}$, on the ordinate axis: on $a-$ glycosidase activity $(\mu \mathrm{mol} /(\mathrm{g} \cdot \mathrm{min}))$, on $b$ - relative enzyme activity $(\%$ of the maximum activity taken as 100); 1 - in the absence of phenol, 2 - in the presence of the upper fraction of amorphous phenol, 3 - in the

presence of the lower fraction of amorphous phenol

The effect of phenol on the temperature coefficients $\left(Q_{10}\right)$ of the activity of peptidases and glycosidases in the whole body of chironomid larvae. Data on the temperature coefficients of the activity of peptidases and glycosidases in the whole body of chironomid larvae indicate that $\mathrm{Q}_{10}$ values in most cases are lower than 2.0, and in the zone of postmaximal temperatures they are below than 1.0 (Table 1).

\section{Table 1}

The effect of phenol on the $\mathrm{Q}_{10}$ values of peptidases and glycosidases in the whole body of chironomid larvae ( $\mathrm{pH} 7.4)$

\begin{tabular}{|c|c|c|c|c|c|c|c|}
\hline \multirow[b]{2}{*}{ Substrate } & \multicolumn{7}{|c|}{$\mathrm{Q}_{10}$} \\
\hline & $\begin{array}{c}0- \\
10^{\circ} \mathrm{C}\end{array}$ & $\begin{array}{c}10- \\
20^{\circ} \mathrm{C}\end{array}$ & $\begin{array}{c}20- \\
30^{\circ} \mathrm{C}\end{array}$ & $\begin{array}{c}30- \\
40^{\circ} \mathrm{C}\end{array}$ & $\begin{array}{c}40- \\
50^{\circ} \mathrm{C}\end{array}$ & $\begin{array}{c}50- \\
60^{\circ} \mathrm{C}\end{array}$ & $\begin{array}{c}60- \\
70^{\circ} \mathrm{C}\end{array}$ \\
\hline Casein 1 & 1.1 & 1.4 & 1.4 & 1.4 & 0.4 & 0.6 & 0.7 \\
\hline Casein, 2 & 1.4 & 1.4 & 1.8 & 2.3 & 0.4 & 0.3 & 0.6 \\
\hline Hemoglobin, 1 & 1.7 & 1.4 & 1.9 & 2.2 & 0.4 & 0.4 & 0.4 \\
\hline Hemoglobin, 2 & 1.3 & 1.5 & 1.5 & 2.0 & 0.6 & 0.4 & 0.2 \\
\hline Starch, C 1 & 1.2 & 1.2 & 1.2 & 1.2 & 1.1 & 0.4 & 0.1 \\
\hline Starch, C 2 & 1.0 & 1.3 & 1.3 & 1.2 & 1.1 & 0.5 & 0.1 \\
\hline Starch, A 1 & 1.4 & 1.5 & 1.4 & 1.4 & 1.6 & 0.5 & 0.4 \\
\hline Starch, A 2 & 1.4 & 1.4 & 1.4 & 1.5 & 1.2 & 0.5 & 0.4 \\
\hline Starch, A 3 & 1.3 & 1.4 & 1.3 & 1.3 & 1.3 & 0.3 & 0.4 \\
\hline
\end{tabular}

Note: 1 - in the absence of phenol, 2 and 3 - in the presence of phenol; $\mathrm{C}$ - crystalline phenol, A - amorphous phenol (A 2 - upper fraction, A 3 lower fraction).

In the case of peptidases in the whole body of chironomid larvae, the highest values of the indicator were found in the temperature range $30-40^{\circ} \mathrm{C}$. At the temperature range of $20-40^{\circ} \mathrm{C}$, casein-lytic peptidases functioning in the presence of amorphous phenol showed higher $\mathrm{Q}_{10}$ values than in the control. The $\mathrm{Q}_{10}$ values of hemoglobin-lytic peptidases, on the contrary, were lower in the experiment than in the control in this temperature range. It is important to note that in the temperature zone of active life of chironomid larvae $\left(10-30^{\circ} \mathrm{C}\right)$, the fluctuations in the $\mathrm{Q}_{10}$ values of casein-lytic peptidases are absent. The $\mathrm{Q}_{10}$ values of glycosidases in control chironomid larvae from the Kuchurgan Reservoir were lower in the temperature range $30-40{ }^{\circ} \mathrm{C}$ than those of peptidases, but they were higher in the zone $40-50{ }^{\circ} \mathrm{C}$. In the presence of crystalline phenol, $\mathrm{Q}_{10}$ values change slightly. In the case of amorphous phenol despite the higher $\mathrm{Q}_{10}$ values the pattern noted above remains. 
The effect of phenol on the energy of the activation $\left(E_{\text {act }}\right)$ of the process of protein and polysachcaride hydrolysis by peptidases and glycosidases of the whole body of chironomid larvae. Data concerning the values of $\mathrm{E}_{\mathrm{act}}$ of the hydrolysis process of the proteins by the peptidases functioning in the whole body of chironomid larvae in the range of the temperature of their vital activity $\left(0-30^{\circ} \mathrm{C}\right)$ indicate the dependence of the values of this parameter on the substrate, $\mathrm{pH}$, and the presence of phenol (Table 2).

\section{Table 2}

The effect of phenol on the energy of the activation of the process of protein and polysachcaride hydrolysis by the enzymes of the whole body of chironomid larvae in the temperature range of their life activity $\left(0-30^{\circ} \mathrm{C}\right)$

\begin{tabular}{lccc}
\hline \multirow{2}{*}{ Substrate } & \multicolumn{3}{c}{ Energy of activation, kcal/mol } \\
\cline { 2 - 4 } & $\begin{array}{c}\text { before } \\
\text { break point }\end{array}$ & $\begin{array}{c}\text { after } \\
\text { break point }\end{array}$ & $\begin{array}{c}\text { break } \\
\text { point }\end{array}$ \\
\hline Casein 1 & 3.5 & 6.5 & $20{ }^{\circ} \mathrm{C}$ \\
Casein, 2 & 5.5 & 12.6 & $20{ }^{\circ} \mathrm{C}$ \\
Hemoglobin, 1 & 6.8 & 13.2 & $20{ }^{\circ} \mathrm{C}$ \\
Hemoglobin, 2 & 5.1 & 10.1 & $20{ }^{\circ} \mathrm{C}$ \\
Starch, C 1 & 3.0 & 3.0 & $-*$ \\
Starch, C 2 & 2.3 & 2.3 & - \\
Starch, A 1 & 6.1 & 6.1 & - \\
Starch, A 2 & 6.5 & 6.5 & - \\
Starch, A 3 & 4.7 & 4.7 & - \\
\hline
\end{tabular}

Note: see Table 1; a dash in the last column indicates no inflection on the Arrhenius chart.

It is important to emphasize, that there was a break on the Arrhenius plots in the case of the protein hydrolysis by peptidases of the whole body of chironomid larvae at $20^{\circ} \mathrm{C}$. Moreover, the $\mathrm{E}_{\text {act }}$ values of the process of casein hydrolysis in the temperature range $0-20^{\circ} \mathrm{C}$ in the control were 1.9 times lower than in the zone of higher temperatures. The $\mathrm{E}_{\text {act }}$ values of the casein hydrolysis increase in the presence of phenol in both temperature zones (1.6 and 1.9 times, respectively). In the study the hemoglobin, as a substrate, the $\mathrm{E}_{\text {act }}$ values were smaller in the zone of low temperatures than in the zone of higher temperatures by 1.9 and 2.0 times in the control and the experiment, respectively. The $\mathrm{E}_{\text {act }}$ values of the process of hemoglobin hydrolysis decreased by 1.3 times in the presence of phenol in both temperature zones. The Arrhenius plots of polysaccharide hydrolysis differ from that of protein hydrolysis by the absence of a break. In this case, the $\mathrm{E}_{\text {act }}$ values of the process of starch hydrolysis decreased in the presence of crystalline phenol by 1.3 times. The $\mathrm{E}_{\text {act }}$ values of the process of polysaccharide hydrolysis increased by 1.1 times in the presence of the upper fraction of amorphous phenol and they decreased by 1.3 times in the presence of the lower fraction of amorphous phenol.

\section{Discussion}

First of all, it should be noted that we investigated integrative indicators reflecting the activity of a number of peptidases and glycosidases. So, in the case of peptidases, the activity of trypsin and chymotrypsin are of the greatest importance. The first hydrolyzes predominantly the peptide bonds adjacent to lysine or arginine, the second predominantly hydrolyzes the peptide bonds adjacent to tyrosine, tryptophan, and phenylalanine (Dixon \& Webb, 1983). It is also important to emphasize that there is no information on the effect of phenol on the activity and characteristics of peptidases and glycosidases in chironomid larvae in the available literature. However, the activity of trypsin-like and chymotrypsin-like enzymes was found in representatives of the Arthropoda taxonomically similar to chironomids: lobsters (Navarrete del Toro et al., 2006), spiny lobsters (Kim et al., 1992), crabs (Dendinger, 1987; Sakharov et al., 1994; Navarrete del Toro et al., 2006) and shrimps (Van-Wormhoudt et al., 1995). In some invertebrates, the activity of carboxypeptidases A and B, as well as leucine aminopeptidases, were revealed (Elyakova \& Kozlovskaya, 1975; Dendinger, 1987; Glass \& Stark, 1995).

Data on the activity of casein-lytic and hemoglobin-lytic peptidases in the whole body of chironomid larvae are largely close to the pre- viously obtained results at a standard temperature and $\mathrm{pH}$ (Kuz'mina et al., 2018). However, when studying the activity of peptidases in chironomid larvae from the Kuchurgan Reservoir under the same methodological conditions, a higher level of enzymatic activity was revealed: $3.1 \pm 0.16 \mu \mathrm{mol} /(\mathrm{g} \cdot \mathrm{min})$. It should be especially noted that phenol decreases significantly the activity of casein-lytic peptidases in adult benthophages: bream Abramis brama (L.), silver bream Blicca bjoerkna (L.), roach Rutilus rutilus (L.), and ichthyophage pike Esox lucius L. At the same time, significant changes in the enzymatic activity were not detected in the ichthyophage zander Sander lucioperca (L.) and the benthophage-facultative ichthyophage perch Perca fluviatilis L. over the entire range of studied phenol concentrations (Kuzmina et al., 2017a).

The temperature characteristics of peptidases of chironomid larvae differ significantly from those of fish. So, the temperature optimum of casein and hemoglobin-lytic peptidases of the intestinal mucosa in fish of different species corresponds to 50 or $60^{\circ} \mathrm{C}$ (Ugolev \& Kuz'mina, 1993 ) and in chironomid larvae it is $50^{\circ} \mathrm{C}$ (Kuz'mina, 1999) or $40{ }^{\circ} \mathrm{C}$ (Kuz'mina et al., 2018). This may be due to the differences in the sources of enzymes. At the same time, the shape of the temperature dependence curves of casein-lytic and hemoglobin-lytic peptidases in the low and postmaximal temperature zones is different. This may be due to the functioning of various hydrolases. The data regarding the stimulating effect of amorphous phenol on the activity of peptidases is in good agreement with the data obtained in the study of crystalline phenol (Kuz'mina et al., 2016). Particular attention should be paid to the fact that the level of peptidase activity increases significantly in the presence of amorphous phenol in the temperature optimum zone in the case of both substrates. These data confirm the pattern identified earlier in the study of the effect of temperature on the effects of modifiers that change the activity of various digestive enzymes of fish (Ugolev \& Kuz'mina, 1993). It can be assumed that in our experiments, as in experiments on the effect of modifiers on the temperature dependence of fish digestive hydrolases, maximum effects are observed at temperatures conducive to maintaining optimal conformation of enzymes. However, the activity of glycosidases decreases in almost the entire range of temperatures under the action of crystalline and amorphous phenols. This fact is essential for the life of chironomid larvae, since oxygen levels are lowered in the bottom layers of the water. In this regard, the role of aerobic respiration decreases and the role of the glycolysis increases in benthic animals (Goromosova \& Shapiro, 1989). Therefore, a decrease in glucose production resulting from the hydrolysis of polysaccharides can adversely affect the viability of chironomid larvae. Especially important is the fact that the lower phenol fraction causes the greatest inhibitory effect.

The data on the temperature coefficients of chironomid larvae enzymes confirm the classical notion on a sharp decrease in $\mathrm{Q}_{10}$ values in the zone of postmaximal temperatures as a result of denaturation of their protein globules. Accordingly, phenol increases the $\mathrm{Q}_{10}$ values of casein-lytic peptidases and decreases the values of hemoglobin-lytic peptides in the temperature range of $20-40^{\circ} \mathrm{C}$. A comparison of the values of one of the fundamental characteristics of enzymes, namely $\mathrm{E}_{\text {act }}$, indicates the dependence of these values on the substrate. It should be especially noted that lower values of $\mathrm{E}_{\text {act }}$ of the process of protein hydrolysis in the zone of low temperatures contributes to better digestion and assimilation of the protein components of feed in comparison with the zone of higher temperatures in adverse conditions. The decrease of $E_{\text {act }}$ values of the process of hemoglobin hydrolysis at low temperatures in the presence of amorphous phenol, as well as their decrease in the case of polysaccharide hydrolysis in the range of $0-40{ }^{\circ} \mathrm{C}$ in the presence of crystalline phenol and the lower fraction of amorphous phenol, is of similar importance.

The obtained data testify to the different effects of amorphous phenol on the activity of peptidases and glycosidases. It was shown that molecular-mass characteristics of protein components which dominate in the tissues of chironomid larvae correspond to those of hemoglobin, and that glycogen is the main carbohydrate component. It was also shown that food components that are not substrates of the analyzed reactions, in particular tributyrin, can stimulate or inhibit the activity of various glycosidases in fish of different species (Ugolev \& Kuz'mina, 1993). The revealed facts were explained from the standpoint of allo- 
steric regulation of enzyme activity (Jacob \& Monod, 1961; Koshland $\&$ Neet, 1968). Allosteric enzymes have spatially separated catalytic and regulatory (allosteric) centers. The catalytic activity of the enzymes is changed as a result of the binding of certain substances called modifiers with their regulatory centers (Koshland \& Neet, 1968). The binding of a modifier (effector) with the regulatory center of the enzyme leads to conformational changes in the enzyme molecule and to a change in their affinity for the substrate. Since it is assumed that allosteria can be a property of almost all proteins, it is possible that the effects of phenols are associated with this exactly mechanism.

\section{Conclusion}

The effects of crystalline and amorphous phenol on the activity of peptidases and glycosidases that function in the whole body of chironomid larvae Chironomus sp. (food objects of adult benthophages and juvenile fish of various ecological groups) are different and largely depend on the temperature and $\mathrm{pH}$. The temperature optimum of peptidases in chironomid larvae corresponds to $40{ }^{\circ} \mathrm{C}$. The temperature optimum of glycosidases is $50^{\circ} \mathrm{C}$. The optimum $\mathrm{pH}$ of glycosidases is 8.0 . Under the influence of amorphous phenol, the activity of casein-lytic peptidases increases significantly in the temperature range of $30-50^{\circ} \mathrm{C}$ and hemoglobin-lytic peptidases in the temperature range of $0-60{ }^{\circ} \mathrm{C}$. Crystalline phenol decreases the activity of glycosidases in comparison to the control in the temperature range $0-50{ }^{\circ} \mathrm{C}$, amorphous phenol - in the temperature range $0-70{ }^{\circ} \mathrm{C}$. Moreover, the activity of glycosidases decreases in comparison to the control in the $\mathrm{pH}$ range of 5-11 (to a greater extent in the case of the lower fraction). The $\mathrm{Q}_{10}$ values of casein-lytic peptidases increase in most cases. The $\mathrm{Q}_{10}$ values of hemoglobin-lytic peptidases decrease in the presence of amorphous phenol. Crystalline phenol weakly affects the $\mathrm{Q}_{10}$ values of the glycosidases in the almost all temperature range. Both fractions of amorphous phenol significantly reduce the $\mathrm{Q}_{10}$ values at a temperature of $40-50{ }^{\circ} \mathrm{C}$. The process of protein hydrolysis is characterized by a break in the Arrhenius plots at $20^{\circ} \mathrm{C}$. The values of $\mathrm{E}_{\text {act }}$ are lower in the range 0 $20^{\circ} \mathrm{C}$ than in the zone of higher temperatures. The $\mathrm{E}_{\text {act }}$ values of the process of casein hydrolysis by peptidases of all tissues of chironomid larvae in the presence of amorphous phenol in both temperature zones increase. The $\mathrm{E}_{\text {act }}$ values of the process of hemoglobin hydrolysis by peptidases of all tissues of chironomid larvae in the presence of amorphous phenol in both temperature zones decrease. The $\mathrm{E}_{\text {act }}$ values of the process of starch hydrolysis in the presence of crystalline phenol decreease. The amorphous phenol changes the $\mathrm{E}_{\text {act }}$ values in different directions. They slightly increase in the presence of the phenol upper fraction, and they decrease in the presence of the phenol lower fraction. The data obtained indicate a significant effect of crystalline and amorphous phenol not only on activity, but also on the characteristics of peptidases and glycosidases that function in the whole body of chironomid larvae. The presence of phenol in water can influence the processes of induced autolysis in benthophages and in juvenile fish of various ecological groups that actively consume chironomid larvae.

The work was performed as part of a state assignment of FASO Russia (topic No. AAAA-A18-118012690102-9).

\section{References}

Ali, S. M., Sabac, S. Z., \& Fayez, M., Moniband, M., \& Hegazi, N. A. (2011). The influence of agro-industrial effluents on River Nile pollution. Journal of Advanced Research, 2, 850-895.

Clayton, G. D., \& Clayton, F. E. (1994). Patty's industrial hygiene and toxicology. John Wiley \& Sons Inc., New York.

Dendinger, J. E. (1987). Digestive proteases in the midgut gland of the Atlantic blue crab, Callinectes sapidus. Comparative Biochemistry and Physiology, $88 \mathrm{~B}(2), 503-516$.

Diaz-Tenorio, L. M., Garcia-Carreňo, F. L., \& Navarrete del Toro, Á. M. (2006). Characterization and comparison of digestive proteinases of the Cortez swimming crab, Callinectes bellicosus, and the arched swimming crab, Callinectes arcuatus. Invertebrate Biology, 125(2), 125-135.
Dittrich, B. (1990). Temperature dependence of the activities of trypsin-like proteases in decapod crustaceans from different habitats. Naturwissenschaften, $77,491-492$.

Dixon, M., \& Webb, E. C. (1964). Enzymes. 2nd ed. Longmans, Green and Co., London.

Elyakova, L. A., \& Kozlovskay, E. P. (1975). Proteinases of starfishes-I. Comparative Biochemistry and Physiology, 50B, 249-253.

Flerov, B. A. (1989). Ekologo-fiziologicheskiye aspekty toksikologii presnovodnykh zhivotnykh [Ecological and physiological aspects of toxicology of freshwater animals]. Nauka, Leningrad (in Russian).

Flerova (Nazarova), E. A., \& Zabotkina, E. A. (2012). Toksicheskoye deystviye subletal'nykh kontsentratsiy fenola i naftalina na mezonefros serebryanogo karasya [The toxic effect of sublethal concentrations of phenol and naphthalene on mesonefros of silver crucian carp]. Toxicological Herald, 4, 49-51 (in Russian).

Ford, M. D., Delaney, K. A., Ling, L. J., \& Erickson, T. (2001). Clinical toxicology. W. B. Saunders Company, Philadelphia.

Gad, N. S., \& Saad, A. S. (2008). Effect of environmental pollution by phenol on some physiological parameters of Oreochromis niloticus. Global Veterinaria, 2, 312-319.

Gerasimov, U. V. (ed.). (2015). Rybi Rybinskogo vodokhranilishcha: Populyatsiolnnaya dinamika i ekologiya [Fish of the Rybinsk Reservoir: Population dynamics and ecology]. Filigran, Yaroslavl (in Russian).

Gerking, S. D. (1994). Feeding ecology of fish. Acadtmic Press, San-Diego.

Glass, H. J., \& Stark, J. R. (1995). Carbohydrate digestion in the European lobster Homarus gammarus (L.). Journal of Crustacean Biology, 15(3), $424-433$.

Goromosova, S. A., \& Shapiro, A. Z. (1989). Osnovnyye cherty biokhimii energeticheskogo obmena midiy [The main features of the biochemistry of energy metabolism of mussels]. Nauka, Moscow (in Russian).

Goronovskiy, I. T., Nazarenko, Y. P., \& Nekryach, Y. F. (1987). Kratkiy spravochnik po khimii [A concise handbook to chemistry]. Naukova Dumka, Kiev (in Russian).

Hori, T. S. F., Avilez, I. M., Iwama, G. K., Johnson, S. C., Moraes, G., \& Afonso, L. O. B. (2008). Impairment of the stress response in matrinxa juveniles (Brycon amazonicus) exposed to low concentrations of phenol. Comparative Biochemistry and Physiology, 147C, 416-423.

Hori, T., Avilez, I. M., Inoue, L. K., \& Moraes, G. (2006). Metabolical changes induced by chronic phenol exposure in matrinxa Brycon cephalus (Teleostei: Characidae) juveniles. Comparative Biochemistry and Physiology, 143, 67-72.

Jacob, F., \& Monod, J. (1961). On the regulation of gene activity. Cold Spring Harbor Symposium on Quantitative biology. Vol. 26.

Kamler, E., Wolnicki, J., Kamiński, R., \& Sikorska, J. (2008). Fatty acid composition, growth and morphological deformities in juvenile cyprinid, Scardinius erythrophthalmus fed formulated diet supplemented with natural food. Aquaculture, 278, 69-76.

Kim, H. R., Meyers, S. P., Pyeun, J. H., \& Godber, J. S. (1994). Enzymatic properties of anionic trypsins from the hepatopancreas of crayfish, Procambarus clarkia. Comparative Biochemistry and Physiology, 107B, 197-203.

Koshland, D. E. J. (1970). The molecular basis for enzyme regulation. The enzymes. Structure and Control. New York, London, 342-396.

Koshland, D. E. J., \& Neet, K. E. (1968). The catalytic and regulatory properties of enzymes. Annual Review of Biochemistry, 37, 359-410.

Kuz'mina, V. V., Tarleva, A. F., \& Gracheva, E. L. (2017). Influence of various concentrations of phenol and its derivatives on the activity of fish intestinal peptidases. Inland Water Biology, 10, 228-234.

Kuz'mina, V. V. (1999). Vliyaniye temperatury na pishchevaritel'nyye gidrolazy bespozvonochnykh zhivotnykh [The effect of temperature on digestive hydrolases of invertebrate animals]. Journal of Evolutionary Biochemistry and Physiology, 35(1), 15-19 (in Russian).

Kuz'mina, V. V., Chornaya, E. Y., Kulivatskaya, E. A., \& Sheptitskiy, V. A. (2017b). Vliyaniye fenola na temperaturnyye kharakteristiki peptidaz lichinok khironomid - potentsial'nykh ob'yektov pitaniya ryb-bentofagov [The effect of phenol on the temperature characteristics of peptidases of chironomid larvae - potential food objects for benthophagous fish]. Problems of Biology of Productive Animals, 4, 48-57 (in Russian).

Kuz'mina, V. V., Chornaya, E. Y., Skvortsova, E. G., Kulivatskaya, E. A., \& Sheptitskiy, V. A. (2018). Temperature characteristics of peptidases of chironomid larvae, potential fish prey, at various $\mathrm{pH}$ values. Biosystems Diversity, 3, 201-205.

Kuz'mina, V. V., Zavedenkova, L. V., \& Gracheva, E. L. (2016). Vliyaniye fenola i yego proizvodnykh na aktivnost' kazeinliticheskikh peptidaz u lichinok khironomid - potentsial'nykh ob'yektov pitaniya ryb [The effect of phenol and its derivatives on the activity of caseinlitic peptidases in chironomid larvae - potential fish food objects]. Problems of Biology of Productive Animals, 4, 37-45 (in Russian).

Luk'yanenko, V. I. (1983). Obshchaya ikhtiotoksikologiya [General ichthyotoxicology]. Light and Food Industry, Moscow (in Russian). 
Mai, I. D. (2012). Experimental exposure of African catfish Clarias gariepinus (Burchell, 1822) to phenol: Clinical evaluation, tissue alterations and residue assessment. Journal of Advanced Research, 3, 177-183.

Matey, V. Y. (1970). Vliyaniye subtoksicheskikh kontsentratsiy fenola na uslovnoreflektomuyu deyatel'nost' guppi [The effect of subtoxic phenol concentrations on guppy conditioned activity]. Hydrobiological Journal, 6(3), 100-103.

Maystrenko, V. N., \& Klyuyev, H. A. (2004). Ekologo-analiticheskiy monitoring stoykikh organicheskikh zagryazniteley [Ecological and analytical monitoring of persistent organic pollutants]. BINOM, Moscow (in Russian).

Michałowicz, J., \& Duda, W. (2007). Phenols - sources and toxicity. Polish Journal of Environmental Studies, 16(3), 347-362.

Mikryakov, V. R., Balabanova, P. V., Zabotkina, E. A., Lapirova, T. B., Popov, A V., \& Silkina, N. I. (2001). The reaction of the immune system of fish to water pollution with toxicants and acidification of the environment. Nauka, Moscow.

Navarrete del Toro, M. A., García-Carreño, F. L., Díaz, L. M., Celis-Guerrero, L., \& Saborowski, R. (2006). Aspartic proteinases in the digestive tract of marine decapod crustaceans. Journal of Experimental Zoology, 305A, 645-654.

Orlov, D. S., Sadovnikova, L. K., \& Lozanovskaya, I. N. (2002). Ekologiya i zashchita biosfery pri khimicheskom zagryaznenii [Ecology and protection of the biosphere in chemical contamination]. Higher School, Moscow (in Russian).

Pinder, L. C. V. (1986). Biology of freshwater Chironomidae. Annual Review of Entomology, 31, 1-23.

Sakharov, I. Y., Litvin, F. E., Mitkevitch, O. V., Samokhin, G. P., \& Bespalova, Z D. (1994). Substrate specificity of collagenolytic proteases from the king crab
Paralithodes camtschatica. Comparative Biochemistry and Physiology, 107B(3), 411-417.

Singh, A. K., \& Chandra, R. (2019). Pollutants released from the pulp paper industry: Aquatic toxicity and their health hazards. Aquatic Toxicoljgy, 211, 202-216.

Taysse, L., Troutaud, D., Khan, N. A., \& Deschaux, P. (1995). Structure-activity relationship of phenolic compounds (phenol, pyrocatechol and hydroquinone) on natural lymphocytotoxicity of carp (Cyprinus carpio). Toxicology, 98, 207-214.

Ugolev, A. M., \& Jesuitova, N. N. (1969). Determination of the activity of invertase and other disaccharidases. In: Study of the digestive apparatus in humans. Overview of modern methods. Nauka, Leningrad. Pp. 169-173 (in Russian).

Ugolev, A. M., \& Kuz'mina V. V. (1993). Pishchevaritel'nyye protsessy i adaptatsii u ryb [Digestive processes and adaptations in fish]. Gidrometeoizdat, Saint Petersburg (in Russian).

Van Wormhoudt, A., Sellos, D., Donval, A., Plaire-Goux, S., \& Le Moullac, G. (1995). Chymotrypsin gene expression during the intermolt cycle in the shrimp Penaeus vannamei (Crustacea; Decapoda). Experientia, 51(2), 159-163.

Wardiatno, Y., \& Krisanti, M.. (2013). The vertical dynamics of larval chironomids on artificial substrates in Lake Lido (Bogor, Indonesia). Tropical Life Sciences Research, 24(2), 13-29.

Zaprometov, M. N. (1974). Osnovy biokhimii fenol'nykh soyedineniy [Principles of biochemistry of phenolic compounds]. Publishing Graduate School M, Moscow (in Russian)

Zilli, F. L., Montalto, L., Paggi, A., \& Merchese, C. (2008). Biometry and life cycle of Chironomus calligraphus Goeldi 1905 (Diptera, Chironomidae) in laboratory conditions. Asociacion Interciencia, 33(10), 767-770. 